\title{
FARM RESPONSE TO CLIMATE CHANGE: EXPLORATORY ANALYSIS OF MACEDONIAN AGRICULTURE USING THE RICARDIAN MODELING APPROACH
}

\author{
Aleksandra Martinovska Stojcheska ${ }^{1^{*}}$, Jordan Hristov ${ }^{2}$, Yves Surry ${ }^{3}$ \\ ${ }^{1}$ Faculty of Agricultural Sciences and Food, Ss. Cyril and Methodius University, \\ Skopje, Republic of Macedonia \\ ${ }^{2}$ Formerly at Department of Economics, Swedish University of Agricultural Sciences (SLU), \\ Uppsala, Sweden \\ ${ }^{3}$ Department of Economics, Swedish University of Agricultural Sciences (SLU), \\ Uppsala, Sweden \\ e-mail: amartinovska@fznh.ukim.edu.mk
}

\begin{abstract}
Agriculture is one of most vulnerable sectors in the country, with the imminent intensification of global warming effects. In this paper, we attempt to assess the adaptation of Macedonian crop farmers to the impact of climate change. An alternative specification of the Ricardian model is adopted by using a composite aridity index to capture the response of farm returns to temperatures and precipitations. The econometric results indicate the significance of winter and summer season weather-related variables and confirm the non-linearity of the climatic function in relation to the farmers' economic results and adaptation capacity. The farm returns are highly sensitive to different climate change scenarios and tend to decrease unless adequate adaptation and mitigation measures take place, both at micro and macro levels.
\end{abstract}

Key words: Ricardian modeling approach; climate change; crop farms; Macedonian agriculture; aridity index

\section{INTRODUCTION}

Global warming and climate change are at this point a recognized threat and a top priority on policy makers' agendas (Angelini et al. [1]). Climate change will influence all spheres of living to a certain extent, but unquestionably, it will have a deep effect on agricultural systems through higher temperatures, greater crop water demand, more variable rainfalls, and weather extremes (Sutton et al. [2]).

Agriculture is particularly important for the Macedonian economy as a major contributor to the national gross domestic product (around $10 \%$, or $15 \%$ with the food industry) and as a major employment and social absorber. Indeed, agriculture is a direct or indirect generator of income and livelihood in rural areas; it employs roughly $20 \%$ of the population (442 thousand engaged persons or 243 thousand full-time equivalents, SSO [3]).

The country is classified in the Continental South agro-climatic zone in Europe, where it is ex- pected that climate change brings potential changes in the precipitation pattern consisting of increased rainfall in winter and decreased water availability in summer (Iglesias et al. [4]). Although Macedonia is a small landlocked country "comparable to a single grid-cell of current global climate models that are used to simulate the future climate change in a large scale", there is great variance in elevation and high heterogeneity in climate conditions (Bergant [5]). Three major types of climate can be distinguished (Aladzajkov [6]): i) moderate Continental climate, ii) modified Mediterranean climate and iii) Mountain climate. The annual temperature cycle is divided into a warm summer and relatively cold winter connected with transitional seasons of spring and autumn. Another important characteristic of the Macedonian climate is the uneven spatial distribution of precipitations throughout the country, by seasons and years. Usually there are periods of droughts, followed by high intensity rainfalls, which contribute to soil erosion and land degradation (MEPP [7]). 
Climate change projections foresee a severe impact over the next 30 years that could lead farmers losing up to half of certain crops' yields (rainfed maize, apple, grapes, vegetables) under the medium impact scenario, unless adaptation measures are implemented (Sutton et al. [8]). Similarly to the previous finding, other sources (Bergant [5], MEPP [7], MEPP [9]) estimate in the period between 2025 and 2100 a continuous increase in temperature, especially in the summer, and a decline in precipitations in all seasons and at annual level, most emphasized or even absent in the months of July and August. Additionally, substantial water shortages are projected, especially for the Crna River basin, which will affect the water availability for irrigation purposes.

The impacts of climate change and identified areas where adaptation may be necessary were the focus of few studies (Callaway et al. [10], Sutton et al. [2] and [8], MEPP [9]). They conclude that climate change will have an impact on the reduction of yields in most crops and additionally assess that water resource management implications of the forecast change in climate could be severe, with increased water shortages especially during the summer season. Adaptation is pointed out as the key remedy for addressing climate change effects; "without adaptation, the climate change damages may grow to become approximately the same or bigger than current net income - jeopardizing the economic sustainability of farming in some areas" (Callaway et al., p. 16 [10]). With these challenges in mind, the aim of this article is to assess the impact of climate change and farmers' adaptation in the Macedonian context using a Ricardian model approach.

\section{METHOD}

This section presents the Ricardian modelling approach as it has been used in the literature and applied in the United States, Europe or other continents (Mendelsohn and Massetti [11]). As explained further down, the typical Ricardian model specification had to be adapted to this work by considering alternative variables representing climate change. This latter aspect is captured using a measure which in the fields of meteorology and geography is known as the "aridity index".

\section{Traditional Ricardian model}

Hertel and Rosch [12] identify three categories of models that are adequate in assessing the impact of climate change on agriculture: i) crop growth simulations, ii) statistical studies and iii) hedonic
(Ricardian) models. The crop growth simulations use extensive data, and provide highly detailed output, but as a result of that are not applicable on a large area. The statistical methods which analyze the relationship linking climate variables such as temperature and rainfall, and crop yields, have modest data requirements and can be applied on a wide level, but do not consider adaptation, hence they may give results that are extreme, i.e. which are either too optimistic or too pessimistic. The 'Ricardian' approach overcomes this issue with land values as the key variable to explain. It has a moderate requirement for data, accounts for regional level changes, and takes account of farmers' adaptation to the new conditions. It is convenient to use in developing countries, which usually do not have long strains of historical data (Mendelsohn et al. [13]; Mendelsohn and Massetti [11]).

Mendelsohn et al. [13] developed the "Ricardian approach" based on David Ricardo's theory that rent of land is equal to the economic advantage obtained by its most productive use, relative to the advantage obtained by using marginal land for the same purpose (Ricardo [14]). This approach examines "the impact of climate on farm revenue, while including adaptations that farmers would make in response to the changing economic and environmental conditions", by directly measuring farm prices or revenues, hence accounting for the direct impacts of climate change on yields of different crops, substitution of inputs, introduction of diverse activities, and other potential adaptations to different climatic conditions (Mendelsohn et al. [13]).

The Ricardian approach is an economic crosssectional model, with geographic areas as units of observation. The method itself consists of regression analysis of statistical relationships between economic indicators and climate variables; the end-result measures the degree of influence of each factor (climatic and other control variables) on land values. Farmland prices are the first choice as a dependent variable, given that data are readily available and as such were used in a number of studies in the U.S. and Europe (Mendelsohn et al. [13], Chatzopoulos and Lippert [15], Van Passel et al. [16]). However, such indicator is not applicable in many developing or transition countries, due to the lack of data on agricultural farm values and poorly functioning land markets. Instead, the dependent variable used in most studies across the world (but mainly dealing with developing countries) is the net revenue of farms (often expressed on a per hectare basis). This latter approach has been applied in studies of climate change impact on agriculture in Africa (Kurukulasuriya et al. [17], Seo and Mendelsohn [18]), 
South America (Seo and Mendelsohn [19]), and China (Wang et al. [20], Chen et al. [21]).

Generally speaking, the explanatory variables based on the Ricardian model approach could be grouped into few categories: i) climatic, ii) geographical, iii) geophysical/edaphic and iv) socioeconomic variables. Apart from the compulsory presence of temperature and precipitation indicators in an empirical Ricardian model, a combination of other variables is used in the various studies, depending on their availability and relevance. This includes soil attributes (quality, salinity, $\mathrm{pH}$, erosion), altitude, latitude, irrigation, distance from city, population density, labor, etc. Irrigation is also taken into account in some of the studies.

The following formulation of the Ricardian model has been adopted in most of the studies applying this approach so far:

$$
G R_{k}=\alpha+\sum_{i} f_{i}\left(T_{i k}\right)+\sum_{i} h_{i}\left(P_{i k}\right)+\sum_{j} m_{j} G_{j k}+\varepsilon_{k}
$$

In expression (1), $G R_{k}$ is the (unit) gross return (measured in general on a per hectare basis) of the unit of observation $k$ (most likely a farm), $f\left(T_{i k}\right)$ and $h\left(P_{i k}\right)$ are assumed to be quadratic functions of temperatures and precipitations, subscript $i$ refers to seasons, $G$ is a vector of all other control $j$ variables (farm elevation, irrigation, agro-climatic regions, etc.), $\alpha$ and $m_{j}$ are parameters and $\varepsilon$ is the error term.

However, in model (1), the explanatory variables, temperature and rainfall, are more likely to be defined at a macro (region) level, while the dependent variable is defined at a micro (i.e farm) level. There is a potential issue in regressing land rent, observed at micro level, and aggregate variables such as temperatures and rainfall, defined at macro level (region or station proximity), that can lead to difficulties in obtaining robust estimates. If this latter problem is not taken into consideration, it could lead to a spurious regression in estimating the effect of aggregate variables (temperatures and rainfall) on micro units (farms) (Moulton [22]). More specifically, the standard errors of the estimated coefficients could exhibit a downward bias that increases with the average group size, the intraclass correlation of the disturbances and the intraclass correlations of the regressors (ibid).

Another problem that could emerge in the traditional Ricardian model could be that interactions or more complicated nonlinearities between temperatures and rainfall could occur. This problem has been recently evidenced by Fezzi and Bateman [23] in the case of the United Kingdom. Climatologists and geographers have been aware of this problem and for this reason they suggest that so-called aridity indices should be used. To our knowledge, the idea of specifying a Ricardian model using aridity indices has not been explored in the relevant literature and it is one of the objectives of this work to attempt to estimate a Ricardian model where temperatures and rainfall are replaced by an aridity index.

\section{Ricardian model based on the use of aridity index}

The effects of climate through temperature and precipitation on agricultural rents tend to be highly non-linear and vary considerably by season (Mendelsohn et al. [13]; Kurukulasuriya et al. [17]). In order to capture this issue in our study, instead of using second order polynomial forms linking directly the dependent variable to temperatures and precipitations, we introduce the de Martonne (aridity) indicator, implicitly assuming a different (and unconventional) nonlinear function within which precipitations and temperatures interact.

The de Martonne aridity index (DMI), a modification of Lang's rain factor index, is a "relatively simple approach to the problem of allowing for weather influence upon crops in agricultural production analysis" (Oury, p. 270 [24]). This index allows to determine the climatic zone and as such is used in several recent studies linking the aridity index to crop yield (Cukaliev et al. [25], Lungu et al. [26]). The de Martonne index is computed based on the following formulation:

$$
D M I_{i}=\frac{12 P_{i}}{T_{i}+10}
$$

where $P_{i}=$ monthly rainfall for month $i(\mathrm{~mm}), T_{i}=$ average monthly temperature for month $i\left({ }^{\circ} \mathrm{C}\right)$. Low aridity index indicates low degree of moisture, i.e. presence of higher temperatures and lower rainfall. Climatic conditions expressed through DMI values can be classified as extremely dry $(<5)$, dry $(5-15)$, semi-dry (15-20), mildly wet (20-30), wet (30-60) and very humid over 60 (Lungu et al. [26]).

We regress the gross return per ha over the de Martonne index and other control variables:

$$
G R_{k}=\alpha+\sum_{i} l_{i}\left(D M I_{i k}\right)+\sum_{j} m_{j} G_{j k}+\varepsilon_{k}
$$

where $l_{i}\left(D M I_{i}\right)$ is a quadratic function of the aridity index in month or season $i\left(D M I_{i}\right)$ and where $\beta_{1}$ and $\beta_{2}$ are parameters:

$$
l_{i}\left(D M I_{i}\right)=\beta_{1 i} D M I_{i}+0.5 \beta_{2 i}\left(D M I_{i}\right)^{2}
$$


Replacing the $D M I_{i}$ s and $l_{i}\left(D M I_{i}\right)$ functions by their respective expressions (2) and (4) in the Ricardian model specification (3) leads to a complex nonlinear relationship between the dependent variable and the temperatures and rainfall. This will serve as the basis to estimate the Ricardian model in the Macedonian context.

\section{DATA}

The data used in this study are obtained from several sources. For the farm level variables we use the annual Farm Monitoring Survey (FMS) of the National Extension Agency. The empirical application of the Ricardian model is based on 439 observations from 2011. The following farm types producing the respective crops are considered: cereals, fodder and industrial crops (Specialized field crop farms); orchards and vineyards (Perennial crops farms), mixed crop and mixed crop/livestock farms (Mixed farms) and vegetable farms. The FMS source also provides general farm data such as location (village and region) and utilized agricultural area (UAA). Basic economic results such as farm income, specific costs and gross margin are also derived from the FMS survey. The land market in the country is insufficiently developed to allow the use of land values. The use of gross margin as a proxy for the dependent variable instead of net income is justified on the grounds that there is insufficient data with regard to the fixed costs in the FMS survey.

The National Hydro-Meteorological Service gathers climatic data for the territory of Macedonia, such as temperature expressed in Celsius degrees and precipitation measured at monthly sums in millimeters. The variables with meteorological data are obtained from the eight meteorological stations regularly reported by the State Statistical Office, namely: Skopje, Bitola, Prilep, Shtip, Kriva Palanka, Ohrid, Demir Kapija and Berovo (SSO [27]). Farm data are linked with the nearest corresponding meteorological station. In our study, the climatic variables are calculated on a three-month season basis (winter, spring, summer and autumn).

Farm elevations are determined based on the altitude above sea level of the farm village. The soil attributes are extracted from the Macedonian Soil Information System (Filipovski [28], MASIS [29]), following the farm village location and dominant properties ( $\mathrm{pH}$, humus, clay, silt, lime, soil capability).

\section{RESULTS AND DISCUSSION}

We begin this section by providing a brief overview of the main characteristics of the farm sample. Then we present the specification of the Ricardian model assessing the relationship between the farm returns and the key climatic and control variables, followed by impact analysis scenarios and underlining the limitations.

\section{Characteristics of the sample}

An overview of the variables with descriptive statistics is given in Table 1. The average per hectare farm gross return in 2011 is 124 thousand MKD, ranging from 3 to 815 thousand MKD/ha. Looking at different farm types, expectedly, lowest per hectare margins are met at field crop farms and mixed farms (53 and 94 thousand MKD, respectively), followed by perennial crops (176 thousand MKD) and vegetable farms (183 thousand MKD).

The mean seasonal temperature ranges from $2.4{ }^{\circ} \mathrm{C}$ in the winter period to $22.1^{\circ} \mathrm{C}$ in the summer, in all seasons being lowest in Berovo and highest in Demir Kapija. The lowest annual rainfall is recorded by the Stip meteorological station and highest by the Ohrid station. The calculated De Martonne aridity index has peak values in winter, but pointing out to semi-arid conditions and high vulnerability in the remaining seasons. The values in 2011 for all seasons are lower than those reported for the eight meteorological stations for the period of 1971-2000 by Cukaliev et al. [25], especially with regard to the spring and autumn season (with 1971-2000 spring DMI equal to 29 and autumn DMI equal to 32.1, respectively).

In our sample, most farms are within the Mediterranean and Continental zones (only seven farms are located on altitude over $1.000 \mathrm{~m}$ above sea level). In terms of irrigation, only $12 \%$ of the land is reported to have irrigation related costs, as a proxy to this farm practice. In this respect, it is an interesting finding that when cross-analyzed, farms located in areas with lowest De Martonne index apply irrigation most frequently (for instance, in regions with lowest aridity index of 5.0, $50 \%$ of the land is irrigated).

In Table 1, we also report the major soil properties of the land in a farm village (in absence of exact farm land coordinates) and the calculated soil capability index that ranges from 31 to 58 in the sample. 
Table 1. Descriptive statistics $(n=439)$

\begin{tabular}{lcccc}
\hline Variable & Mean & St. Dev & Minimum & Maximum \\
\hline Gross return (MKD/ha) & 123.972 & 119.325 & 3.457 & 814.834 \\
Temperature (winter) $\left({ }^{\circ} \mathrm{C}\right)$ & 2.4 & 1.0 & 0.7 & 3.7 \\
Temperature (spring) $\left({ }^{\circ} \mathrm{C}\right)$ & 10.9 & 1.7 & 8.2 & 13.3 \\
Temperature (summer) $\left({ }^{\circ} \mathrm{C}\right)$ & 22.1 & 2.3 & 18.5 & 25.4 \\
Temperature (autumn) $\left({ }^{\circ} \mathrm{C}\right)$ & 11.5 & 1.8 & 8.1 & 13.5 \\
Precipitation (winter) $(\mathrm{mm})$ & 135.8 & 20.3 & 105.8 & 160.6 \\
Precipitation (spring) (mm) & 104.1 & 20.9 & 77.9 & 144.5 \\
Precipitation (summer) (mm) & 94.5 & 48.1 & 44.4 & 169.2 \\
Precipitation (autumn) (mm) & 102.9 & 17.7 & 82.2 & 126.6 \\
De Martonne index (winter) & 44.0 & 7.3 & 32.2 & 52.6 \\
De Martonne index (spring) & 20.2 & 4.3 & 13.8 & 28.7 \\
De Martonne index (summer) & 12.2 & 6.9 & 5.0 & 23.7 \\
De Martonne index (autumn) & 19.3 & 4.4 & 14.7 & 28.0 \\
Elevation (m) & 494 & 266 & 41 & 1223 \\
UAA per farm (ha) & 4.5 & 9.2 & 0.2 & 120.7 \\
Irrigated UAA per farm (ha) & 0.6 & 1.8 & 0.0 & 26.9 \\
Distance to town (km) & 10.4 & 6.9 & 0.0 & 43.0 \\
pH value & 6.9 & 0.7 & 5.3 & 8.3 \\
Humus (\%) & 2.7 & 1.1 & 0.0 & 8.0 \\
CaCO $(\%)$ & 3.9 & 4.9 & 0.0 & 42.0 \\
Clay (\%) & 12.9 & 6.8 & 3.0 & 36.0 \\
Sand $(\%)$ & 60.9 & 8.3 & 41.0 & 83.0 \\
Silt (\%) & 26.3 & 6.9 & 12.0 & 54.0 \\
Favorability (soil capability index) & 50.9 & 4.7 & 58.0 \\
\hline
\end{tabular}

Ricardian model specification of Macedonian farmers' adaptation to climate change

The empirical implementation of the modified Ricardian model used in this work leads us to select an estimated model specification as presented in Table 2. The dependent variable in the model is the unit farm return (gross margin per ha) expressed in a logarithmic form. Initially, we specify regressions with climatic variables (aridity indices), along number of control variables such as irrigation, elevation, distance to town, latitudinal data and the extracted farm proximate soil properties. However, these estimated model specifications exhibit a low explanatory power, but also reveal poor and unstable statistical significance of numerous control variables, which stem from a strong multicollinearity among these control variables. Hence, we reduce the presented model specification to the core climatic variables and the farm type dummy variables. The model is estimated with the Ordinary Least Squares estimation method. Despite a low explanatory power as shown by the value of adjusted $\mathrm{R}^{2}$ equal to 0.275 , an F-statistical test of zero slopes rejects the null hypothesis of no impact on the dependent variables of the selected climatic (aridity indices) and other control (farm type) variables.

The estimated model aims to capture the farm type effects by dummy variables (mixed crop farms as the reference type), since the impact of climate change on farm revenue reflects not only yields variations but also crop substituting (Seo and Mendelsohn [19]). The econometric results indicate that the gross margin for mixed farm group is on average not significantly different from the reference mixed crop farm. The specialized field crops farm estimated coefficient is significant, but interestingly, with negative effect, suggesting that this strategy to focus on field crops and not diversify into other types of production does not contribute to higher returns to the farmer. Some adaptation measures, such as adjustment of sowing dates and cultivation depth, as well as irrigation, are proposed as beneficial in avoiding or lessening the negative effects of climate change in field crops farming (MEPP [9]). The specialized vegetable farms and perennial farm types (orchards and vineyards) dummy variables are statistically significant and positively related to the unit farm gross returns, thus showing that it is more profitable to grow vegetables, fruit and grapes relative to a mixed farm. 
Table 2. Econometric results

\begin{tabular}{lcccc}
\hline Explanatory variables & $\begin{array}{c}\text { Estimated } \\
\text { coefficient }\end{array}$ & Standard error & t-statistic & P-value \\
\hline Intercept & 3.12182 & 1.94451 & 1.60545 & 0.109 \\
Mixed farm & -0.129461 & 0.113492 & -1.14071 & 0.255 \\
Specialized field crop farm & -0.591234 & 0.142103 & -4.16061 & 0.000 \\
Specialized vegetable farm & 0.518671 & 0.125188 & 4.14314 & 0.000 \\
Specialized perennial crop farm & 0.488594 & 0.111704 & 4.37401 & 0.000 \\
De Martonne index (DMIwinter) & 0.378100 & 0.097005 & 3.89773 & 0.000 \\
De Martonne index (DMIsummer) & 0.093282 & 0.040130 & 2.32449 & 0.021 \\
De Martonne index (DMIautumn) & -0.026423 & 0.016737 & -1.57869 & 0.115 \\
0.5 $\times$ DMIwinter $\times$ DMIwinter & -0.008517 & 0.002319 & -3.67193 & 0.000 \\
$0.5 \times$ DMIsummer $\times$ DMIsummer & -0.008552 & 0.002886 & -3.03269 & 0.003 \\
\hline Adjusted R $^{2}: 0.275224$ & & & & \\
F statistic(zero slopes): 19.4805 & & & & 0.000 \\
\hline
\end{tabular}

Global warming will cause switch in production structure; some studies imply changes in South American agriculture from cereal production towards fruit and vegetables that succeed in warmer locations (Seo and Mendelsohn [18]), other switch to maize and wheat instead of vegetables in warmer conditions such as expected in China (Wang et al.[20]). Vegetable, fruit and grape systems are more intensive than cereals and other field productions. Production under plastic tunnels is characteristic for early vegetables in Macedonia, as it enables hedging from the outdoor conditions and producing in a protective environment. Fruit and grape production is generally very sensitive to certain weather circumstances (such as spring frosts, hail, extreme high temperatures and uneven rainfall distribution) and typically with high production variations throughout the years due to these climatic factors. Investments in ultraviolet and hail protective nets and more sophisticated irrigation techniques could mitigate many of the effects of global warming. Climate change causes flooding and torrential rainfall in the low altitude Mediterranean zone, and the main issue in the Continental zone is the water availability (Sutton et al. [8]), hence it confirms the positive effect of irrigation. Enhancing some rainfed agricultural systems, such as organic farming (where soil qualities are improved and water use is more efficient), is also seen as part of the mitigation strategy (MEPP [9]).

The climatic variables (measured by de Martonne indices) for the winter and summer seasons are statistically significant, indicating that climate change has an impact on Macedonian farms. In both cases, higher value of the index is associated with an increase in the farm gross margin, albeit with a much stronger estimated coefficient for the winter period and with quite low value for the summer period. Although the estimated coefficient associated with the autumn DMI is not statistically significant at a $10 \%$ level but close to it (p-value equal to 0.115 ), this climatic variable is kept in the estimated model because it shows that season is characterized by a drier climate pattern which results in slowing down crop growth.

All the estimated coefficients associated with the quadratic climatic variable terms are statistically different from zero, which confirms the non-linear relationship between aridity indices and unit gross return. This finding is consistent with the literature (Mendelsohn et al. [13], Kurukulasuriya et al. [17]). We include winter and summer aridity indices, as the extreme seasons with highest and lowest De Martonne values. The squared terms of both the winter and summer aridity indices are negative, implying that their relationship with the farm gross return is inverted-U shaped. This relationship is difficult to interpret, since climate sensitivity of crops varies according to their vegetation phase, but nevertheless points out to hill-shaped functions as the usual response in crop production (Van Passel et al. [16]). Overall, these concave-relationship curves suggest the best adaptation of farmers to be within the mean index values, not the extremes. In winter, too much humidity can cause pests, too little is also not beneficial.

\section{Climate scenario effects on farm returns}

In Table 3, we examine the scale of the global warming effect on the unit farm gross margin. The estimated Ricardian model (Table 2) is used to derive projected changes in the farm returns under different future climatic conditions. We use MEPP [9] 
predicted projections that provide five different precipitation and temperature change scenarios for the years of 2025 and 2050, hence obtaining the absolute changes in the de Martonne index. The marked negative percentage changes in gross margin per ha resulting from the predicted changes in precipitations and temperatures are pointing to pronounced adverse climate change effect across all scenarios, similar to findings in comparative studies (for instance, Van Passel et al. [16] estimate farm land value losses of -5 to $-9 \%$ per ${ }^{\circ} \mathrm{C}$ at farms in South- ern Europe). In our study, farm returns shrunk as the scenarios aggravate and the time period gets longer (5.6\% decrease at the 2025 lowest impact scenario, $23.1 \%$ decrease at the 2025 lowest impact scenario, $28.8 \%$ decrease at 2025 medium impact scenario, etc.). The estimations for the highest impact scenarios are overinflated, but nevertheless this exercise emphasizes the pressing need for farm-level and government-level measures, which will have to take place.

Table 3. Change in climate variables and farm gross margin per ha in different scenarios

\begin{tabular}{|c|c|c|c|c|c|c|c|c|c|c|c|}
\hline & & \multicolumn{5}{|c|}{2025} & \multicolumn{5}{|c|}{2050} \\
\hline & & 름 & $\stackrel{\Xi}{\Xi} \underset{\Xi}{\Xi}$ & 异 & 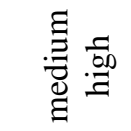 & 告 & 3. & $\stackrel{\Xi}{\Xi} \stackrel{\Xi}{\Xi}$ & 异 & 鸹 & $\frac{5100}{10}$ \\
\hline \multirow{3}{*}{ 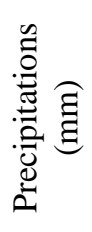 } & Winter & -1 & -1 & -3 & -4 & -5 & -3 & -4 & -6 & -8 & -10 \\
\hline & Summer & -4 & -6 & -13 & -20 & -25 & -12 & -15 & -25 & -38 & -48 \\
\hline & Autumn & -1 & -1 & -2 & -4 & -5 & .5 & -7 & -9 & -11 & -14 \\
\hline \multirow{3}{*}{ 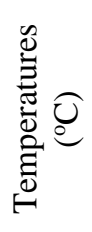 } & Winter & 0.5 & 0.7 & 0.8 & 0.9 & 1.1 & 0.8 & 1 & 1.5 & 1.9 & 2.4 \\
\hline & Summer & 1.2 & 1.6 & 1.7 & 1.9 & 2.4 & 1.5 & 2.1 & 3.0 & 3.8 & 4.8 \\
\hline & Autumn & 0.7 & 1.0 & 1.1 & 1.2 & 1.5 & 1.0 & 1.3 & 1.9 & 2.4 & 3.0 \\
\hline \multirow{4}{*}{ 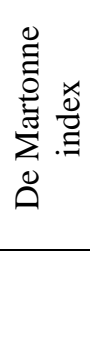 } & Winter & -2.5 & -3.1 & .5 .1 & -6.3 & -7.6 & -5.1 & -6.5 & -9.4 & -12 & -14.5 \\
\hline & Summer & -1.8 & -2.5 & -5.0 & -7.4 & -9.2 & -4.6 & -5.7 & -9.2 & -13.4 & -16.5 \\
\hline & Autumn & -1.1 & -1.3 & -1.9 & -3.0 & -3.7 & -3.4 & -4.6 & -6.0 & -7.2 & -8.9 \\
\hline & $\begin{array}{l}\text { arm gross } \\
\text { margin/ha }\end{array}$ & $-5.7 \%$ & $-9.1 \%$ & $-28.8 \%$ & $-48.7 \%$ & $-71.2 \%$ & $-23.1 \%$ & $-35.1 \%$ & $-81.4 \%$ & $-151.1 \%$ & $-222.8 \%$ \\
\hline
\end{tabular}

\section{Limitations of the Ricardian approach in the Macedonian context}

The theoretical and methodological framework underlying the Ricardian modelling approach to the impact of climatic change to agriculture is suitable in the Macedonian context, considering the predicted climate-induced changes hindering agricultural development. Instead of the more traditional approach of using specific crops yields, this approach uses the value of the farmland or net rent and estimates how it is affected by the climate in different regions. One of the basic assumptions of the $\mathrm{Ri}-$ cardian approach is that every farmer tends to maximize profits by adapting the production to the changing environment. Further assumption is that there is no change in real crop prices in response to climate change, which may be considered as a disadvantage of the model (Cline [30]). Critical comments on this model focus, on one hand, on the exclusion of the adaptation adjustment costs (Hertel and Rosch [12]), while Quiggin and Horowitz [31], on the other hand, challenge the comparative static nature of the empirical results. Taking into careful consideration these limitations, yet the Ricardian (hedonic) model is viewed as the best suited ap- 
proach in most widely received economic studies, since the strength of this approach is that it accounts, to a large extent, for behavioral responses (Schlenker and Roberts [32]).

The most notable limitations of the present study are of empirical nature, namely the available type and quality of data, and hence the need to use different types of proxies in order to assess factors important in the adopted modeling framework. Although we were able to acquire micro-level farm data containing the basic economic indicators, still many essential variables were difficult to obtain. For instance, irrigation could be assessed only through water costs, while in reality some farmers would irrigate, but either not report or not recognize a certain expenditure as an irrigation related cost. Nevertheless, not including irrigation as a variable in the specification does not necessarily mean bias in the model. Schlenker and Roberts [32] argue that irrigation critically influences predicted climate impacts, but Seo and Mendelsohn [18] suggest that although their results show that irrigation lessens the damages of the climate change, there are no conclusive results indicating that not including irrigation in an empirical Ricardian model will yield a significant bias. Vanschoenwinkel and Van Passel [33] suggest farm irrigation response to climate change to be significantly different, depending on how irrigation is defined. The soil variables are not significant regressors - one explanation could be that since we do not have information on the exact location of the farm land plots, we have taken into account the dominant village soil type and properties, but still it does not seem to be influencing the farm gross margin. Latitudinal data are also insignificant, as the country is small and stretches across a small space. Distance to town is also insignificant, although it is expected that an important factor inflating farm land value can be proximity to urban centers due to nonagricultural pressure (Chatzopoulos and Lippert [15]), but also that farm returns can often be higher due to market vicinity, more marketing options and higher prices. Some of these issues may be overcome by conducting a tailor-made survey, or supplementing the annual farm accounting survey with several focused control variables through an accompanying questionnaire.

\section{CONCLUSIONS}

The Ricardian approach is a widely applied and popular analytical model when assessing the impact of climate change on agriculture. It estimates climate-induced changes in farm returns and captures the first-round adaptations by farmers as ap- proximation of the economic value of climate change on agriculture (Mendelsohn et al. [13]). Taking into consideration the particularities of the Macedonian conditions, and the availability and reliability of data, this approach has been modified for the purpose of this study. The adapted specification combines temperature and precipitation, as key explanatory variables, into a single index (de Martonne aridity index), and uses it as such in the model regression.

Recent studies have raised the issue on climate change, reporting the predictions on the nature and scale of the impact (Sutton et al. [2] and [8], Bergant [5], MEPP [7], Callaway et al. [10], MEPP [9]). There is improved awareness of this issue, but still it is not highly positioned in the policy framework. These studies have stressed the need for adaptation and proposed concrete courses of action in order to mitigate the effect. This study captures the adaptations with the current farming systems, as a response to the changing climate. In this respect, we attempt to add to the efforts to increase the understanding of the impact of climate change on Macedonian agriculture and its sensitivity, as the study discloses that climate change has influence on farm returns.

Climate change will affect the choice of crops and influence the production structure, moving towards systems that are more efficient in using the available resources, especially water and soils. Traditional and innovative adaptation measures must take place in a timely manner in order to prevent and handle the expected weather climate change effects; irrigation, as the key responding strategy to the inadequate rainfall during vegetation period, combined with different supplementary adjustments such as introducing heat-resistant varieties, protective netting, increase in vegetable production under protected areas, advanced plastic or glass tunnels etc.

It is important to close this paper by stressing the fact that the empirical results presented herein are exploratory and further in-depth investigation must be conducted. The empirical analysis can be further refined by examining more closely the characteristics of the non-linear response of unit farm returns of crop farms to precipitations and temperature.

Acknowledgments. The empirical work reported in this paper was initiated under the Unicoop project funded by the Swedish International Development Cooperation Agency (SIDA). The authors gratefully acknowledge the financial support received from SIDA. The views expressed in this paper are solely those of the authors and do not necessarily represent those from SIDA and the institutions they work for. Any remaining errors are the responsibility of the authors. 


\section{REFERENCES}

[1] S. Angelini, E. Guardagno, M. Montini, F. Volpe, L. Nikolayeva, O. Simonett, H. Egerer, P. C. Sandei, Climate change adaptation in South Eastern Europe, ENVSEC/UNEP, Venice, 2011.

[2] W. R. Sutton, J. P. Srivastava, J. E. Neumann, Looking Beyond the Horizon: How Climate Change Impacts and Adaptation Responses Will Reshape Agriculture in Eastern Europe and Central Asia, World Bank, Washington, DC, 2013.

[3] SSO, State Statistical Office, State Statistical Yearbook 2017, Skopje, 2018.

[4] A. Iglesias, K. Avis, M. Benzie, P. Fisher, M. Harley, N. Hodgson, L. Horrocks, M. Moneo, J. Webb, Adaptation to Climate Change in the Agricultural Sector. Report to European Commission Directorate - General for Agriculture and Rural Development, AGRI-2006-G4-05 AEA Energy\&Environment, Didcot, 2007.

[5] K. Bergant, Climate Change Scenarios for Macedonia - Summary, University of Nova Gorica, Nova Gorica, 2006.

[6] L. Aladzajkov, Collection and Study of Vegetables and small fruits from throughout Macedonia, Final Report Project No. E30-SR-33, Institute of Agriculture, Skopje, 1974.

[7] MEPP, Ministry of Environment and Physical Planning, Second national communication on climate change, MEPP, Skopje, 2008.

[8] W. R. Sutton, J. P. Srivastava, J. E. Neumann, K. Strzepek, B. Boehlert, Reducing the Vulnerability of FYR Macedonia's Agricultural Systems to Climate Change: Impact Assessment and Adaptation Options, World Bank, Washington, DC, 2013.

[9] MEPP, Ministry of Environment and Physical Planning, Third national communication on climate change, MEPP, Skopje, 2014.

[10] J. M. Callaway, N. Markovska, O. Cukaliev, A. Causevski, D. Gjoshevski, V. Taseska, S. Nikolova, Assessing the Economic Impact of Climate Change: National Case studies, UNDP, Skopje, 2011.

[11] R. Mendelsohn, E. Massetti, The use of crosssectional analysis to measure climatic impacts on agriculture: Theory and evidence, Review of Environmental Economics and Policy, 11, 2 (2017), pp. 280-298.

[12] T. W. Hertel, S. D. Rosch, Climate Change, Agriculture, and Poverty, Applied Economics Perspectives and Policies, 32, 3 (2010), pp. 355-385.

[13] R. Mendelsohn, W. Nordhaus, D. Shaw , The impact of Global Warming on Agriculture: A Ricardian Analysis, The American Economic Review, 84, 4 (1994), pp. 753-771.

[14] D. Ricardo, On the Principles of Political Economy and Taxation, John Murray, London, 1817.
[15] T. Chatzopoulos, C. Lippert, Adaptation and climate change impacts: A structural Ricardian analysis of farm types in Germany, Journal of Agricultural Economics, 66, 2 (2015), pp. 537-554.

[16] S. Van Passel, E. Massetti, R. Mendelsohn, A Ricardian analysis of the impact of climate change on European agriculture, Environmental and Resource Economics, 67, 4 (2017), pp. 725-760.

[17] P. Kurukulasuriya, R. Mendelsohn, R. Hassan, J. Benhin, T. Deressa, M. Diop, H. Eid, Y. Fosu, G. Gbetibouo, S. Jain, A. Mahamadou, R. Mano, J. Kabubo-Mariara, S. El-Marsafawy, E. Molua, S. Ouda, M. Ouedraogo, I. Séne, D. Maddison, N. Seo, A Dinar, Will African Agriculture Survive Climate Change?, World Bank Economic Review, 20, 3 (2006), pp. 367-388.

[18] N. Seo, R. Mendelsohn, A Structural Ricardian Analysis of Climate Change Impacts and Adaptations in African Agriculture. Policy Research Working Paper 4603, World Bank, Washington DC, 2008.

[19] N. Seo, R. Mendelsohn, Climate Change Impacts on Latin American Farmland Values: The Role of Farm Type. Revista de Economia e Agronegocio 6, 2 (2008), pp. 161-176.

[20] J. Wang, R. Mendelsohn, A. Dinar, J. Huang, R. Rozelle, L. Zhang, The impact of climate change on China's agriculture, Agricultural Economics, $\mathbf{4 0}$ (2009), pp. 323-337.

[21] Y. Chen, Z. Wu, K. Okamoto, X. Han, G. Ma, H. Chien, J. Zhao, The impacts of climate change on crops in China: A Ricardian analysis, Global and Planetary Change, 104 (2013), pp. 61-74.

[22] B. R. Moulton, An illustration of a pitfall in estimating the effects of aggregate variables on micro units, The Review of Economics and Statistics, 72, 2 (1990), pp. 334-338.

[23] C. Fezzi, I. Bateman The impact of climate change on agriculture: Non-linear effects and aggregation bias in Ricardian models of farmland values, Journal of Association of Environmental and Resource Economists, 2 (2015), pp. 57-92.

[24] B. Oury, Allowing for weather in crop production model building, Journal of Farm Economics, 47, 2 (1965), pp. 270-283.

[25] O. Cukaliev, D. Mukaetov, S. Andonov, P. Ristevski, I. Minchev, Second communication to UNCCC, Sector Agriculture, Skopje, 2006.

[26] M. Lungu, L. Panaitescu, S. Niţa. Aridity, climatic risk phenomenon in Dobrudja, Present environment and sustainable development 5, 1 (2011), pp. 179190.

[27] SSO, State Statistical Office, State Statistical Yearbook 2011, Skopje, 2012. 
[28] Gj. Filipovski, Soil maps of the Republic of Macedonia, Contributions, Sec. Math. Tech. Sci., MANU, 37, 2 (2016), pp. 55-68.

[29] MASIS, Macedonian Soil Information System, http://194.149.130.132/masis/ [accessed 09.2018]

[30] W. Cline, The impact of global warming on agriculture: Comment, American Economic Review, 86, 5 (1996), pp. 1309-1312.

[31] J. C. Quiggin, J. K. Horowitz, The impact of global warming on agriculture: A Ricardian analysis-
Comment, American Economic Review, 89, 4 (1999), pp. 1044-1045.

[32] W. Schlenker, M. J. Roberts, Estimating the impact of climate change on crop yields: The importance of non-linear temperature effects, Discussion Paper 0607-01, Columbia University, New York, 2006.

[33] J. Vanschoenwinkel, S. Van Passel, Climate response of rainfed versus irrigated farms: the bias of farm heterogeneity in irrigation, Climatic Change, 147, 1-2 (2018), pp. 225-234.

\title{
ДОХОДОТ НА ФАРМИТЕ И КЛИМАТСКИТЕ ПРОМЕНИ: АНАЛИЗА НА МАКЕДОНСКОТО ЗЕМЈОДЕЛСТВО СО КОРИСТЕЊЕ НА РИКАРДИСКИОТ ПРИСТАП НА МОДЕЛИРАҢЕ
}

\author{
Александра Мартиновска-Стојческа ${ }^{1}$, Јордан Христов $^{2}$, Ив Сури $^{3}$ \\ ${ }^{1}$ Факултет за земјоделски науки и храна, Универзитет „Св. Кирил и Методиј“, \\ Скопје, Република Македонија \\ ${ }^{2}$ Formerly at Department of Economics, Swedish University of Agricultural Sciences (SLU), \\ Uppsala, Sweden \\ ${ }^{3}$ Department of Economics, Swedish University of Agricultural Sciences (SLU), \\ Uppsala, Sweden
}

Земјоделството е еден од најранливите сектори во земјата со оглед на интензивирањето на ефектите на глобалното затоплување. Во овој труд се обидуваме да ја процениме адаптацијата на македонските производители под влијанието на климатските промени. Воведуваме алтернативна спецификација на Рикардискиот модел преку вклучување композитен ариден индекс за да се опфати реакцијата на доходот на фармите во однос на температурите и врнежите. Економетриските резултати укажуваат на значајност на променливите поврзани со зимските и летните сезони и ја потврдуваат нелинеарноста на климатската функција во однос на економскиот резултат на фармерите и капацитетот за адаптација. Доходот на фармите е високо чувствителен на различни сценарија за климатски промени и ке се намалува доколку не се преземат соодветни мерки за приспособување и ублажување, на микро и на макро ниво.

Клучни зборови: Рикардиски пристап на моделирање; климатски промени; растителни фарми; македонско земјоделство; ариден индекс 